This is an author produced version of a paper published in Bioresource Technology. This paper has been peer-reviewed and is proof-corrected, but does not include the journal pagination.

Citation for the published paper:

Ahlgren, S., Baky, A., Bernesson, S., Nordberg, Å., Norén, O., Hansson, P-A.

(2009) Ammonium nitrate fertiliser production based on biomass environmental effects from a life cycle perspective. Bioresource Technology.

Volume: 99 Number: 17, pp 8034-8041. http://dx.doi.org/10.1016/j.biortech.2008.03.041

Access to the published version may require journal subscription.

Published with permission from Elsevier

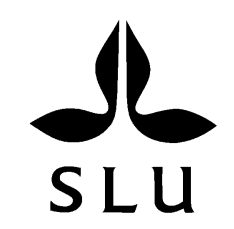

Epsilon Open Archive http://epsilon.slu.se 


\title{
Ammonium nitrate fertiliser production based on biomass - environmental effects from a life cycle perspective
}

\author{
Serina Ahlgren ${ }^{\mathrm{a}, *}$, Andras Baky ${ }^{\mathrm{b}}$, Sven Bernesson ${ }^{\mathrm{a}}$, Åke Nordberg ${ }^{\mathrm{b}}$, Olle Norén ${ }^{\mathrm{b}}$, \\ Per-Anders Hansson ${ }^{\text {a }}$ \\ ${ }^{a}$ Swedish University of Agricultural Sciences, Department of Energy and Technology, P.O. Box 7032, \\ SE 75007 Uppsala, Sweden; e-mail of corresponding author: serina.ahlgren@et.slu.se \\ ${ }^{\mathrm{b}}$ Swedish Institute of Agricultural and Environmental Engineering (JTI), P.O. Box 7033, SE 75007 \\ Uppsala, Sweden.
}

\begin{abstract}
Ammonium nitrate and calcium ammonium nitrate are the most commonly used straight nitrogen fertilisers in Europe, accounting for $43 \%$ of the total nitrogen used for fertilisers. They are both produced in a similar way; carbonate can be added as a last step to produce calcium ammonium nitrate. The environmental impact, fossil energy input and land use from using gasified biomass (cereal straw and short rotation willow (Salix) coppice) as feedstock in ammonium nitrate production were studied in a cradleto-gate evaluation using life cycle assessment methodology. The global warming potential in the biomass systems was only $22-30 \%$ of the impact from conventional production using natural gas. The eutrophication potential was higher for the biomass systems due to nutrient leaching during cultivation, while the acidification was about the same in all systems. The primary fossil energy use was calculated to be 1.45 and 1.37 MJ per kg nitrogen for Salix and straw respectively, compared to $35.14 \mathrm{MJ}$ for natural gas. The biomass production was assumed to be self-supporting with nutrients by returning part of the ammonium nitrate produced together with the ash from the gasification. For the production of nitrogen from Salix, it was calculated that $3914 \mathrm{~kg}$ of nitrogen can be produced every year from 1 ha, after that $1.6 \%$ of the produced nitrogen has been returned to the Salix production. From wheat straw, $1615 \mathrm{~kg}$ of nitrogen can be produced annually from 1 ha, after that $0.6 \%$ of the nitrogen has been returned.
\end{abstract}

Keywords: Nitrogen fertiliser production, biomass feedstock, life cycle assessment, land use, global warming, eutrophication, acidification

\section{Introduction}

Since the establishment of large-scale production of mineral nitrogen fertilisers in the $1950 \mathrm{~s}$, the potential yield of plant biomass per hectare has increased dramatically. At present, about $85 \mathrm{Mt}$ of nitrogen are produced annually worldwide (Smil, 2001). The need for fertilisers is also bound to increase in the future, when a growing world population will need to produce food and biomass for energy purposes on a finite amount of land (Smeets and Faaij, 2005).

\footnotetext{
* Corresponding author. Address: Swedish University of Agricultural Sciences, Department of Energy and Technology, P.O. Box 7032, SE 75007 Uppsala, Sweden; Tel.: +46 18 671887; Fax: +46 186735 29; E-mail address: Serina.Ahlgren@et.slu.se
} 
Unfortunately, production of nitrogen fertiliser is very energy-consuming, accounting for $1.2 \%$ of global primary energy demand. The energy requirement per $\mathrm{kg}$ nitrogen has dramatically decreased over time, from about $55 \mathrm{GJ} /$ metric ton of ammonia produced in the 1950 s to $35 \mathrm{GJ} /$ ton in the 1970 s, while nowadays the best plants need only 27 $\mathrm{GJ} /$ ton. However, since a number of old plants are still in operation, the global average energy requirement is at present somewhere between 40-45 GJ/ton ammonia (Smil, 2001). Production is most commonly based on natural gas, but gasification of coal and heavy oil also occurs (Appl, 1999). Because the production is based on fossil fuel, it can be seen in many life cycle assessment studies that the production of nitrogen fertilisers is one of the major contributors to greenhouse gas emissions from agriculture (see for example Engström et al., 2007). Natural gas is also a limited resource that eventually will run out or become very expensive to use.

The basic component in current industrial nitrogen fertiliser production is ammonia. Ammonia is formed in the Haber-Bosch process, the overall reaction being $\mathrm{N}_{2}+3 \mathrm{H}_{2} \rightarrow$ $2 \mathrm{NH}_{3}$. The hydrogen originates from natural gas, and the nitrogen from air (EFMA, 2000a). In recent years the possibility of producing hydrogen from biomass has been widely discussed, the hydrogen primarily being intended for propulsion of fuel cell vehicles. However, hydrogen from biomass could also be used for production of ammonia. That means that it would be possible to produce mineral nitrogen fertilisers based on renewable sources. Research is urgently needed to explore this possibility and to determine the positive and negative effects a change in feedstock in fertiliser production would have on the environment.

Hydrogen can be produced from biomass in a number of ways (Chum and Overend, 2001; $\mathrm{Ni}$ et al., 2006). One major pathway is via the thermochemical conversion of biomass (pyrolysis and gasification). Another possibility is to produce methane by anaerobic digestion of biomass, and then produce hydrogen from the methane gas. A different alternative is to use 'green' electricity (e.g. wind, solar or hydro power or biomass combustion) to drive an electrolysis process that splits water into hydrogen and oxygen. Yet another solution could be to collect hydrogen produced by algae and photosynthesising organisms.

Calcium ammonium nitrate and ammonium nitrate granules are the most commonly used straight nitrogen fertilisers in Europe, accounting for $43 \%$ of the nitrogen sold in fertilisers. Nitrogen is also found in urea and in compounds with phosphorus and potassium (EFMA, 2008). Ammonium nitrate is produced by reaction of ammonia and nitric acid. Carbonate can in a last step be added as filler to produce calcium ammonium nitrate (EFMA, 2000b).

The objective of this study was to evaluate the environmental impact, fossil energy input and land use of producing nitrogen fertilisers from gasified biomass compared with conventional production from natural gas. For the evaluation, life cycle assessment (LCA) methodology was used. Two types of biomass source were studied, straw from cereal production and short rotation willow (Salix) coppice, since they have been shown to have a favourable energy balance in terms of input versus output from the field (Börjesson, 1996; Ahlgren et al., 2008). 


\section{Methodology}

Life cycle assessment (LCA) is a useful tool for analysing products or services. LCA enhances the understanding of how alternative systems compare with each other, but also how different sub-processes in a system affect the overall results (Baumann and Tillman, 2004). The environmental performance of the systems studied was calculated using the LCA-based methodology described in the ISO 14000 series standards (ISO, 2006a, 2006b). The energy requirements and emissions contributing to the impact categories studied, from raw material acquisition to industrial gate, were quantified (so called cradle-to-gate study). The potential environmental load, categorised into different impact categories, was then calculated using equivalency factors. The categories studied were land use, primary fossil energy use, global warming potential (GWP) for 100 years, eutrophication potential (AP) and acidification potential (AP).

The eutrophication potential was calculated as $\mathrm{O}_{2}$-equivalents using equivalency factors from Lindfors et al. (1995). According to this, an increased input of nutrients to aquatic systems may lead to an increased production of biomass. The decomposition of this biomass requires oxygen. Further, it is also taken in consideration that when nitrogen compounds are emitted to air, a fraction can reach aquatic systems by deposition. The acidification was calculated as $\mathrm{SO}_{2}$-equivalents using equivalency factors from Lindfors et al. (1995). The acidification is calculated as the amount of protons released in a terrestrial system. Lindfors et al. (1995) suggest two ways of calculating acidification potential, in one including nitrogen compounds and in the other one not. In this study the latter was chosen (the maximum scenario). The global warming potential was calculated using equivalency factors from IPCC (2001). The main equivalency factors used in this study are presented in Table 1.

Table 1. Equivalency factors used in the study

\begin{tabular}{|c|c|c|c|}
\hline & $\begin{array}{c}\text { Global warming potential } \\
(\mathrm{GWP})^{\mathrm{a}}\end{array}$ & $\begin{array}{c}\text { Eutrophication potential } \\
(E P)^{b}\end{array}$ & $\begin{array}{c}\text { Acidification potential } \\
(\mathrm{AP})^{\mathrm{b}}\end{array}$ \\
\hline $\mathrm{CO}_{2}$ & 1 & & \\
\hline $\mathrm{CH}_{4}$ & 23 & & \\
\hline $\mathrm{N}_{2} \mathrm{O}$ & 296 & & \\
\hline NOx & & 6 & 0.7 \\
\hline $\mathrm{NH}_{3}$ & & 16 & 1.88 \\
\hline $\mathrm{SO}_{2}$ & & & 1 \\
\hline $\mathrm{N}$ to water & & 20 & \\
\hline $\mathrm{P}$ to water & & 140 & \\
\hline
\end{tabular}

For the inventory of the industrial nitrogen production, the methodology suggested by Jiménez-González et al. (2000) was used. According to this, generating gate-to-gate inventory data for chemical substances should include the following steps: Search and selection of process; definition of process; calculation of mass balance; calculation of energy balance.

The transport distance for biomass was calculated using the model described in Nilsson (1995) and Overend (1982). According to this, the area from which biomass is collected was assumed to be circular, with the plant in the centre. The average transportation distance is dependent on the biomass requirements of the plant, the road winding factor 
and the available amount of biomass in the area. The scale of the production is limited by economical factors, such as transportation costs for the biomass, and will be of a smaller size than corresponding natural gas based production.

\subsection{Functional unit}

The functional unit was $1 \mathrm{~kg}$ of fertiliser nitrogen, as ammonium nitrate $(33.5 \% \mathrm{~N})$ at the gate of the production facility.

\subsection{System boundaries and delimitations}

The data collected from the literature were chosen to represent the best available technique of today. However, some techniques, such as biomass gasification, are still under development and these figures are predictions of future performances. Emissions from production of capital goods such as machinery and buildings were not included in the calculations since in previous studies they have been found to have little impact on the results when converting biomass to fuel (Bernesson et al., 2004, 2006).

It was assumed that the ammonium nitrate production plants were stand-alone plants, i.e. no other products except natural gas or biomass were imported into the factory. The only products leaving the gate were ammonium nitrate and surplus energy. It was assumed that all high pressure surplus steam was converted to electricity. Low pressure steam was assumed to have no value. The size of the production was assumed to be 150 MW incoming biomass, which will produce 310 metric tons of ammonia per day that in turn will produce 750 metric tons per day of ammonium nitrate $(33.5 \%$ nitrogen content). This is rather large-scale considering the amount of needed biomass. However, compared to natural gas feedstock plants, the production volumes in this study is smaller. A typical ammonia plant based on natural gas produce 1000-1500 metric tons per day (EFMA, 2000a) and ammonium nitrate plants generally produce from a few hundred up to 3600 tons per day (EFMA, 2000b).

Many agricultural and other production systems produce more than one output. The environmental load of the production system therefore has to be allocated between the main product and the by-products. The allocation can be based on e.g. physical or economic properties. In this study, allocation issues arose in two cases; between straw and grain and between the end-products ammonium nitrate and electricity. In grain production, straw is a large volume but low value by-product and thus allocating on physical characteristics would give the straw a large share of the environmental load. Since the main goal for the farmer is to produce grain, not straw, it was considered more reasonable to use economic allocation in this study. Economic allocation was also used to allocate surplus electricity produced in the system.

Another way to deal with by-product problems is to expand the system to consider the end use of the by-products. If the by-product replaces a product in an alternative system, the environmental load of the alternative system is subtracted from the studied system (Baumann and Tillman, 2004). In this study, system expansion was used in the sensitivity analysis to identify changes to the results when different methods of handling by-products were used. 
The crop production from which biomass is harvested for manufacture of ammonium nitrate needs several inputs, such as fuel for tractors and herbicides, as well as fertilisers. It was assumed that part of the ammonium nitrate produced was returned to the plantation/field. Furthermore, bottom ashes from the production plant, which contains valuable phosphorus and potassium, was also assumed to be returned to the growing site. The return of ash to agricultural fields is not regulated by Swedish law. However, there are regulations for spreading of sewage sludge, which could serve as guidelines for upper limit of heavy metals (Gruvaeus and Marmolin, 2007).

\section{Description of the studied systems}

In all systems, the output was ammonium nitrate and electricity at the factory gate. The allocation of impacts to these outputs was based on the price at which the producer could sell the products, excluding taxes. The ammonium nitrate was given a value of $0.78 € / \mathrm{kg} \mathrm{N}(\mathrm{SJV}, 2007)$ and the electricity was valued at $48.4 € / \mathrm{MWh}$, which was the average price of electricity in Sweden in 2006 (Nord Pool, 2007). The production facility was assumed to be located in the Mälardalen region in central Sweden. The biomass was assumed to be grown within the region and the natural gas to be from the North Sea.

\subsection{Production based on natural gas}

As a reference case in the study, steam reforming of natural gas was used for ammonium nitrate production (Figure 1). The natural gas serves both as a product feedstock and as a fuel to run the process.

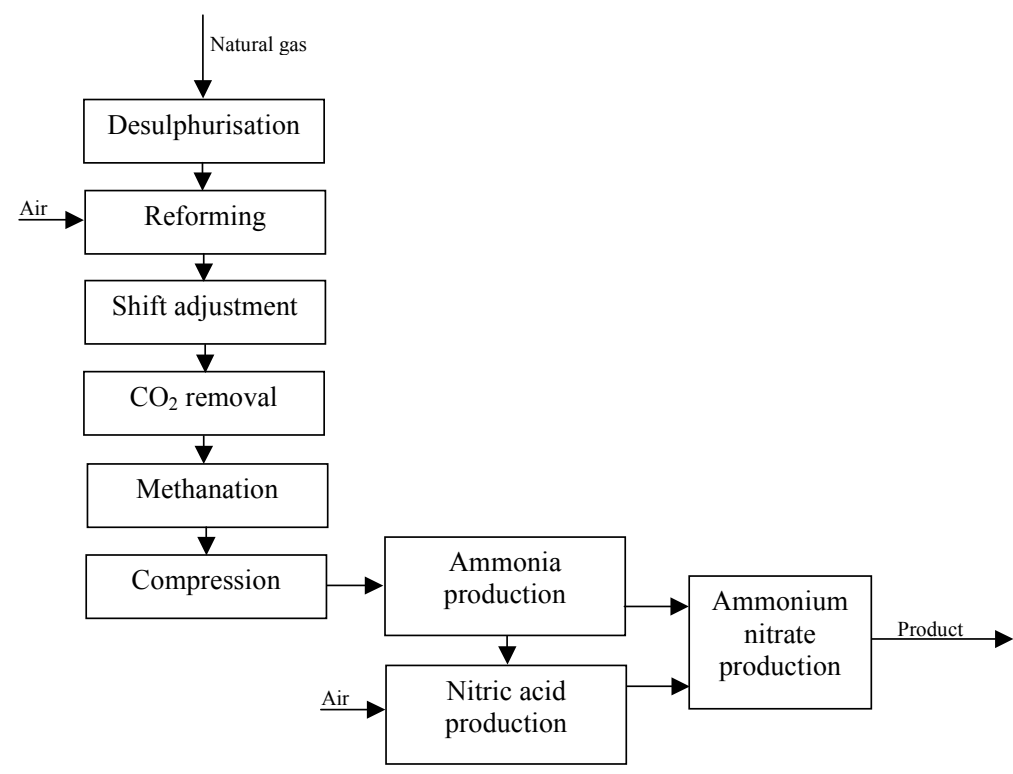

Figure 1. Flow-chart of ammonium nitrate production with natural gas as the feedstock. The hydrogen needed for the ammonia process is derived from the natural gas and the nitrogen from the air. 


\subsubsection{Gas preparation}

The raw natural gas together with air has to be treated in several steps in order to extract the nitrogen and hydrogen needed in ammonia synthesis. The gas treatment steps include desulphurisation, two reforming stages, shift adjustment, $\mathrm{CO}_{2}$-removal, methanation and compression (EFMA, 2000a). The reforming is aimed at splitting the hydrocarbons into smaller substances. In the second reforming step, the temperature of reaction is increased by combusting part of the gas with air, which at the same time supplies the process with nitrogen. In the shift adjustment step, the concentration of hydrogen is improved. Methanation is necessary to remove carbon monoxide and carbon dioxide, as ammonia synthesis is sensitive to these substances (Davis and Haglund, 1999).

\subsubsection{Ammonia production}

The synthesis of ammonia typically takes place over an iron catalyst at pressures of around $100-250$ bar and temperature $350-550^{\circ} \mathrm{C}$. The conversion efficiency to ammonia is low $(20-30 \%)$ and the unreacted gas is recirculated. The ammonia that is formed is separated from the recycle gas by condensation. The reaction is exothermic, generating high pressure steam. Data used in this study for the process were based on the zero steam export scenario found in Dybkjær (2005), where all the steam is utilised in the other processes, reducing the need for natural gas fuel. In an ammonia production facility, the final product is refrigerated. However, the ammonia did not need to be refrigerated in this study as it was assumed to be further processed to ammonium nitrate, which saves energy (Appl, 1999). Emission data for ammonia production via steam reforming of natural gas were based on EFMA (2000a).

\subsubsection{Nitric acid production}

About half the ammonia is further processed to nitric acid (the other half is used in the next step to produce ammonium nitrate, see below). Nitric acid is produced by the exothermic reaction of ammonia and air over a catalyst and the absorption of the product gas in water. In this reaction nitrous oxides $\left(\mathrm{N}_{2} \mathrm{O}\right)$ are generated. However, using a combination of abatement techniques, the $\mathrm{N}_{2} \mathrm{O}$ emissions from a modern plant can be as low as $0.12 \mathrm{~kg} /$ ton nitric acid (100\%) according to IPPC (2007). In the process, high pressure steam is produced (Saigne, 1993) and was here assumed to be converted to electrical energy.

\subsubsection{Ammonium nitrate production}

An ammonium nitrate solution is produced by neutralising the nitric acid with the remaining part of the ammonia in an exothermic reaction. The solution is then evaporated to remove water. A modern plant produces enough heat in the neutralisation to remove the water and no additional heat is needed (Jenssen and Kongshaug, 2003). The ammonium nitrate is thereafter granulated. The electricity requirement is relatively small, $25 \mathrm{kWh} /$ ton ammonium nitrate produced (EFMA, 2000b). Emission data was based on EFMA (2000b).

\subsection{Production based on thermochemical gasification of biomass}

In this option, the hydrogen needed for ammonia synthesis was produced by thermochemical gasification of biomass, and the nitrogen was extracted from outside air 
(Figure 2). The production of hydrogen from biomass via thermochemical conversion generally includes pre-treatment of the biomass, gasification, gas cleaning, reforming and shift conversion followed by separation of hydrogen (Hamelinck and Faaij, 2002). In this study data was taken from the advanced hot gas cleaning option in Hamelinck and Faaij (2002). The separation of hydrogen was assumed to be carried out with a ceramic membrane which has a shifting capability, making extra shift conversion unnecessary. The yield of hydrogen was set to $0.56 \mathrm{MJ}$ MJ-1 dry biomass (LHV) (Hamelinck and Faaij, 2002). In the gasification process, oxygen is needed. This is supplied by an air separation unit, which also supplies the ammonia synthesis with nitrogen. The power needed for the air separation (1.07 MJ per kg produced $\mathrm{N}$ ) and for other utilities in the gasification (2.92 MJ per kg produced $\mathrm{N}$ ) is generated internally of surplus steam from the ammonia and nitric acid production and from expansion of flue gas from the gasification.

The hydrogen and nitrogen are synthesised to ammonia. The conversion efficiency was assumed to be slightly higher than when natural gas is used because of the higher purity of the synthesis gas, comparable to coal gasification (EFMA, 2000a). The rest of the production chain to ammonium nitrate via nitric acid is the same as for the natural gas system.

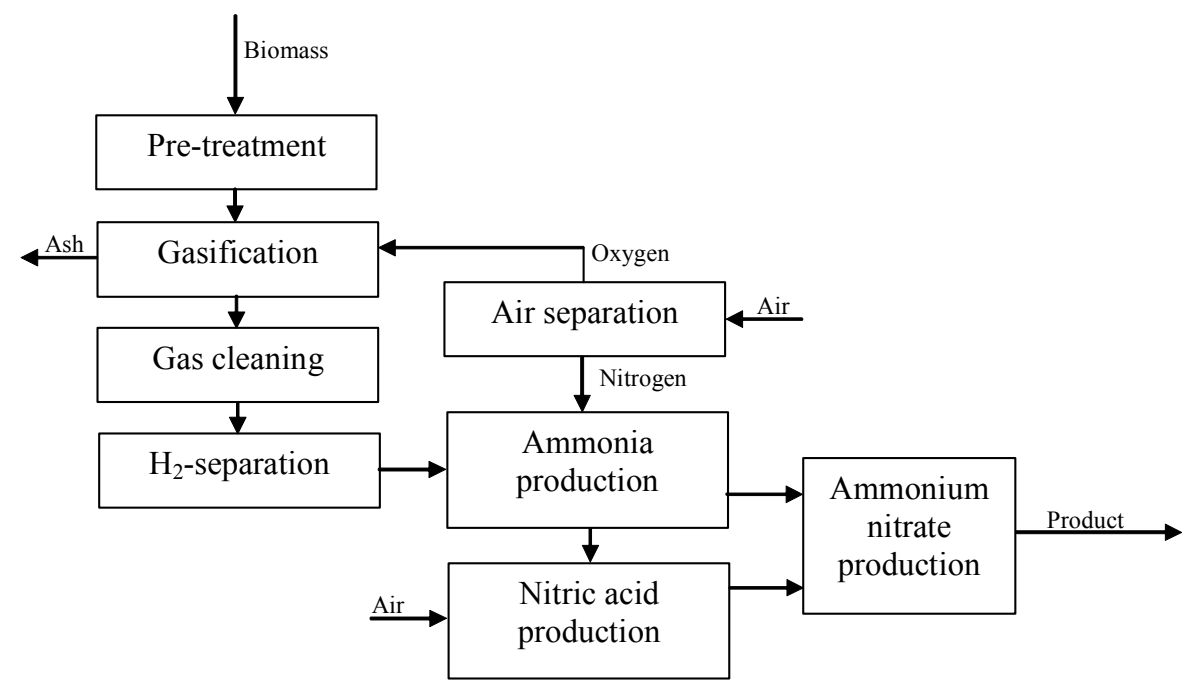

Figure 2. Flow-chart of ammonium nitrate production with biomass as feedstock.

\subsection{Biomass feedstock production}

Short rotation willow coppice (Salix) is grown on farmland to produce biomass for energy purposes. It has a lifetime of about twenty years and is harvested every third or fourth year. At present the yields are low, mainly because the Salix has been planted on marginal land and has been badly managed and because of inappropriate choice of plant varieties (Helby et al., 2006). In this study it was assumed that the Salix was well managed and the average annual yield was estimated at 10000 dry kg ha ${ }^{-1}$ (Lindroth and Bath, 1999; Börjesson, 2006) after losses during harvest, handling and storage. The Salix plantation was assumed to be fertilised with ash and ammonium nitrate from the 
process. The average annual application was $64 \mathrm{~kg} \mathrm{~N} \mathrm{ha}^{-1}$, according to recommendations for commercial Salix cultivation (Gustafsson et al., 2007)

The straw was assumed to be collected from wheat cultivation. To divide the environmental burden, an economic allocation was made between straw and wheat at the field directly after harvest. It was assumed that the straw, if it had not been used for fertiliser production, could have been collected and utilised for example as bedding material. The mass straw-to-grain ratio was set to 0.85 (Nilsson, 1999) giving a straw yield of 4.3 metric ton dry matter ha ${ }^{-1}$. The straw was given a value of $9.6 €$ ton $^{-1}$ dry matter, based on Nilsson (1999) recalculated to the 2005 price level (SCB, 2007a). The wheat was valued at $105.8 €$ ton $^{-1}$ dry matter (SCB, 2007b), resulting in a 7\% allocation from the wheat production to straw. Data for emissions from wheat cultivation were based on Tidåker (2003). It was assumed that $9 \mathrm{~kg}$ of the produced nitrogen was returned to the field, which is $7 \%$ of the wheat need according to the allocation.

When producing biomass for energy, soil emissions generally have a strong influence on the results (Hansson et al., 2007). Data on nitrogen losses to water were taken from Johnsson and Mårtensson (2002) and Dimitriou and Aronsson (2004), assuming the biomass to be grown on clay loam dominated soils in the Mälardalen region of Sweden. Emissions of nitrous oxide were based on data from the Swedish Environmental Protection Agency (2005). According to this, the background emission from soil is 0.5 $\mathrm{kg} \mathrm{N}_{2} \mathrm{O}-\mathrm{N} \mathrm{ha}^{-1}$, while $0.8 \%$ of the applied fertilisers and $2.5 \%$ of the leached nitrogen is volatised to $\mathrm{N}_{2} \mathrm{O}-\mathrm{N}$. It was also assumed that $1 \%$ of applied nitrogen fertiliser was emitted as ammonia based on Välimaa and Stadig (1998). In Salix plantations, fallen leaf litter is not incorporated into the soil and can cause emissions of nitrous oxide. The leaf litter was therefore assumed to give rise to $0.4 \mathrm{~kg} \mathrm{ha}^{1}$ year $^{-1}$ of nitrous oxide, calculated from Aronsson (2000) and the Swedish Environmental Protection Agency (2005). The losses of phosphorus were assumed to be $0.5 \mathrm{~kg} \mathrm{ha}^{-1}$ year ${ }^{-1}$ for all crops, based on Kyllmar and Johnsson (1996).

\subsection{Transport}

The average transportation distance was calculated to be $92 \mathrm{~km}$ in the straw case and 59 $\mathrm{km}$ in the Salix case (see section 2). This is based on the assumptions that the production facility has a requirement of $150 \mathrm{MW}$ LHV incoming biomass and that the road winding factor is 1.8 . In the straw system, $3 \%$ of the land in the circular area around the plant was assumed to be occupied by wheat cultivation (SJV, 2007). The cultivation of Salix is currently limited, but is predicted to expand (SOU, 2007). Assuming that land currently in fallow is utilised for Salix cultivation, $3 \%$ of the land area in the region will be available.

All transport was assumed to be carried out with diesel-powered trucks. Straw was assumed to be transported as large square bales on a truck. As they are bulky, the volume and not the weight is the limiting factor. The energy consumption for straw transport was calculated to be $1.87 \mathrm{MJ} \mathrm{ton}^{-1} \mathrm{~km}^{-1}$ based on Berggren (1999). Salix was assumed to be chipped and transported by truck, with an energy consumption of 1.15 $\mathrm{MJ}$ ton $^{-1} \mathrm{~km}^{-1}$. 
Since the biomass plantations were assumed to be self-supporting in nitrogen fertilisers, part of the nitrogen produced was returned to the field. The ash from the gasification facility, containing valuable phosphorus and potassium, was also assumed to be returned. Data for such transport were taken from NTMCalc (2007).

\section{Results}

\subsection{Results from inventory}

The results of the cradle-to-gate inventory are presented in Table 2 . The figures are the net sums, i.e. the nitrogen requirement of the biomass feedstock cultivation has already been subtracted (see section 2).

From 1 ha of Salix, it was calculated that $3978 \mathrm{~kg}$ nitrogen could be produced per year. The Salix plantation itself requires $64 \mathrm{~kg}$ nitrogen, which means that the net production from 1 ha is thus $3914 \mathrm{~kg}$ of nitrogen and $2670 \mathrm{kWh}$ of electricity. Calculated on a biomass basis, the production of $1 \mathrm{~kg}$ nitrogen requires $2.6 \mathrm{~kg}$ dry Salix.

In the straw system no land needed to be set aside for nitrogen production, but if the straw is collected from 1 ha of wheat, $1624 \mathrm{~kg}$ nitrogen can be produced. It was assumed that $9 \mathrm{~kg}$ nitrogen (equivalent to $7 \%$ of the recommended application in wheat production according to the economic allocation between wheat and straw) was returned to the field, which means that the net production from 1 ha is thus $1615 \mathrm{~kg}$ of nitrogen and $1100 \mathrm{kWh}$ of electricity. Calculated on a biomass basis, the production of $1 \mathrm{~kg}$ nitrogen requires $2.7 \mathrm{~kg}$ dry straw.

Table 2. Inputs, outputs and emissions from cradle to gate for the studied systems

\begin{tabular}{lrrrr}
\hline & $\begin{array}{c}\text { Natural } \\
\text { gas }\end{array}$ & Salix & Straw & \\
\hline $\begin{array}{l}\text { Primary fossil inputs } \\
\text { Natural gas }\end{array}$ & 35.14 & & & $(\mathrm{MJ})$ \\
Diesel & & 1.45 & 1.37 & $(\mathrm{MJ})$ \\
$\begin{array}{l}\text { Outputs } \\
\text { Ammonium nitrate }(33.5 \% \mathrm{~N})\end{array}$ & 3.00 & 3.00 & 3.00 & $(\mathrm{~kg})$ \\
Electricity & 0.97 & 2.45 & 2.45 & $(\mathrm{MJ})$ \\
Emissions & & & & \\
$\mathrm{CO}_{2}$ (non renewable) & 2032 & 106 & 96 & $(\mathrm{~g})$ \\
$\mathrm{CH}_{4}$ & 398 & 55 & 37 & $(\mathrm{mg})$ \\
$\mathrm{N}_{2} \mathrm{O}$ & 1354 & 2136 & 1513 & $(\mathrm{mg})$ \\
$\mathrm{NOx}_{\mathrm{NH}}$ & 1211 & 842 & 937 & $(\mathrm{mg})$ \\
$\mathrm{SOx}$ & 597 & 795 & 731 & \\
$\mathrm{~N}$ to water & 122 & 38 & 35 & $(\mathrm{mg})$ \\
$\mathrm{P}$ to water & 719 & 2310 & 1391 & $(\mathrm{mg})$ \\
& - & 128 & 25 & $(\mathrm{mg})$ \\
\hline
\end{tabular}




\subsection{Results from impact assessment}

\subsubsection{Global warming}

The global warming potential can clearly be reduced by using biomass as feedstock in ammonium nitrate production compared with natural gas (Figure 3). The Salix system contributed to $30 \%$ and straw only $22 \%$ of GWP compared to the natural gas case. In the natural gas system, the conversion of natural gas to ammonia gave a large contribution to the global warming potential, since the process emits $\mathrm{CO}_{2}$. In all systems the formation of nitrous oxides during nitric acid production had an impact on the results. The global warming potential for production of biomass mainly originates from nitrous oxide soil emissions (75\% of GWP of biomass production in the Salix case, and $45 \%$ in the straw case), but also from the use of diesel oil in tractors. Straw was only allocated $7 \%$ of the wheat cultivation soil emissions, hence the relatively small emissions compared with Salix (Figure 3).

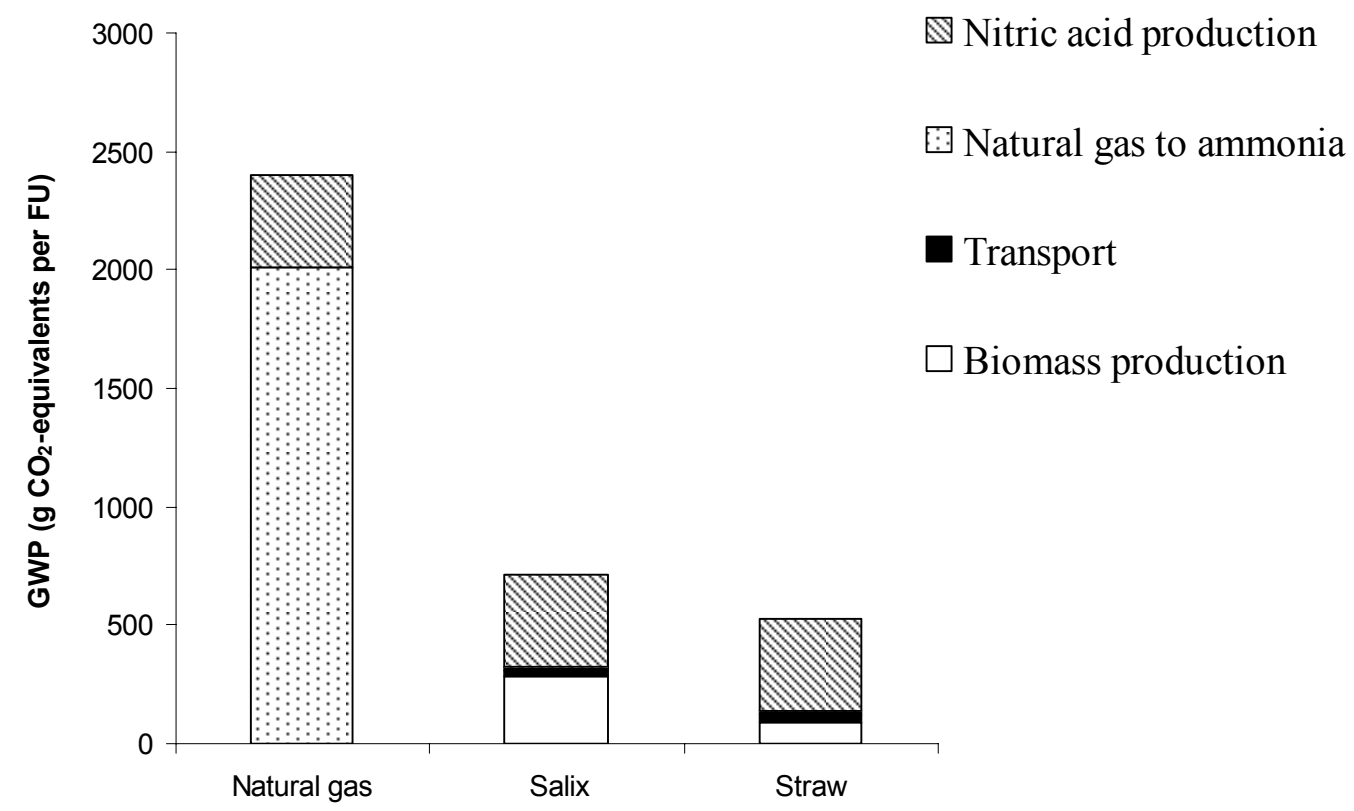

Figure 3. Contribution of different activities to global warming potential $(G W P)$ per functional unit (FU) for the systems studied. Transport includes transport of biomass to production plant and transport of ammonium nitrate and gasification ash to cultivation site.

\subsubsection{Eutrophication}

In the biomass systems, the leaching of nitrogen and phosphorous from soil gave the largest contribution to the eutrophication potential (Figure 4). From ammonium nitrate production some ammonia emissions contributed to eutrophication, but the eutrophication caused by air deposition is minor compared to the contribution by leaching. The leaching from Salix is quite low compared with annual crops, since it has long roots that utilise most of the available nutrients. The straw system was accredited low leaching due to the allocation between wheat and straw mentioned above. 
Compared to the natural gas case, the Salix system gave a $153 \%$ and the straw system $51 \%$ larger contribution to eutrophication.

D Ammonium nitrate production

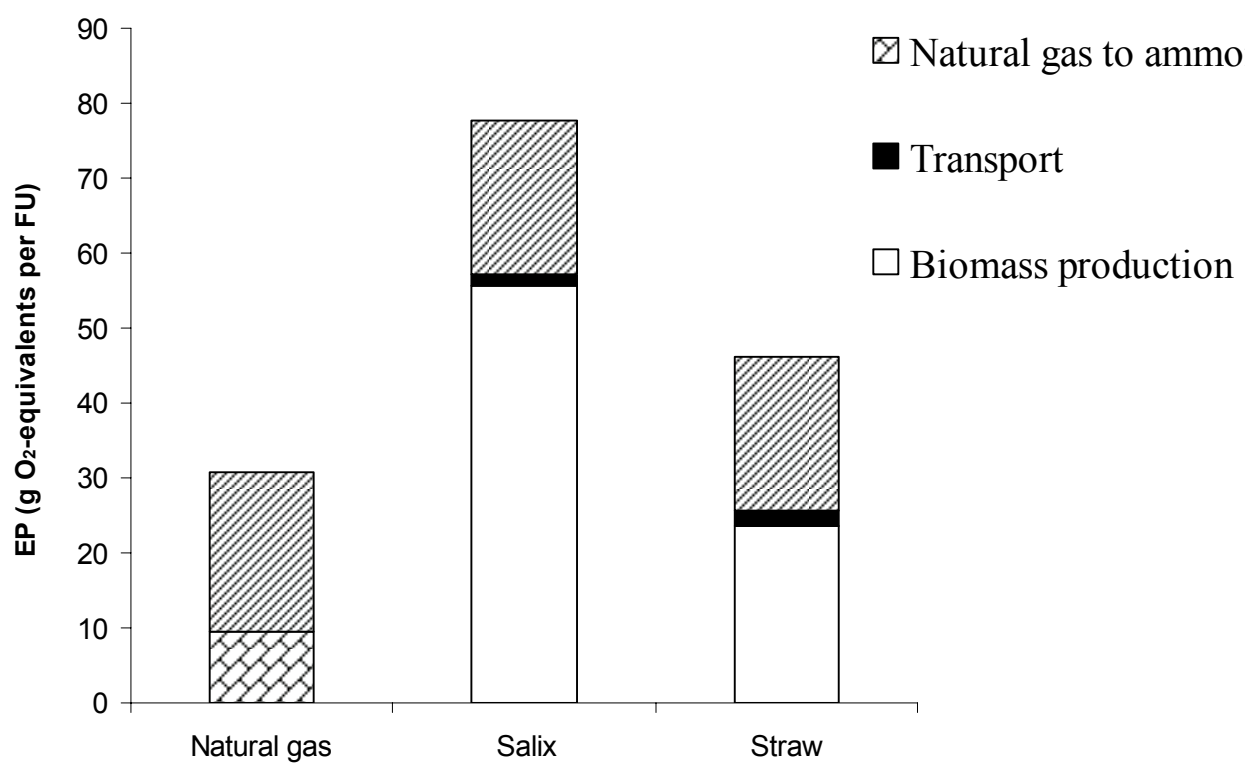

Figure 4. Contribution of different activities to eutrophication potential (EP) per functional unit (FU) for the systems studied. Transport includes transport of biomass to production plant and transport of ammonium nitrate and gasification ash to cultivation site.

\subsubsection{Acidification}

The difference in contribution to acidification potential was small between the systems (Salix 99\% and straw 96\% compared to natural gas) (Figure 5). In the biomass systems, nitrogen oxides (NOx) originating from diesel use in the tractors had a large impact on the results. Furthermore, the ammonium nitrate production emitted ammonia, which affected the acidification potential. In the natural gas case, NOx was formed during combustion of fuel for the process, which gave a contribution to the acidification potential. 


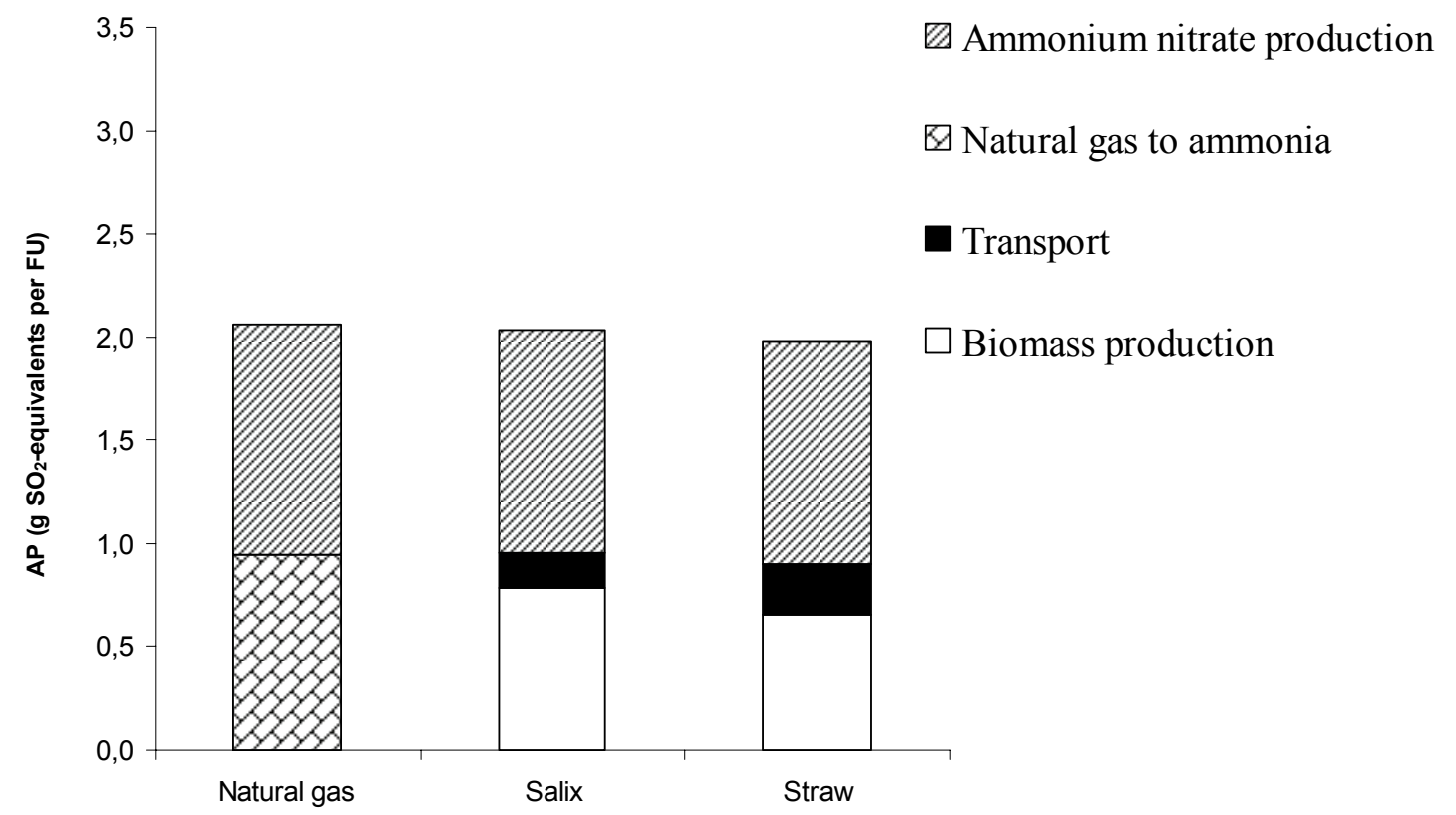

Figure 5. Contribution of different activities to acidification potential (AP) per functional unit (FU) for the systems studied. Transport includes transport of biomass to production plant and transport of ammonium nitrate and gasification ash to cultivation site.

\subsection{Sensitivity analyses}

An analysis was made of the effects on the results of some possible changes in assumptions and input data. The results are presented in Table 3.

The systems produce both ammonium nitrate and electricity, and an allocation was made based on economic value. The effect on the results of a doubled electricity price was evaluated. Choosing another method of allocation, such as system expansion, can also influence the results. An analysis was made in which the surplus electricity from the ammonia production was assumed to replace marginal electricity. The marginal electricity was assumed to be produced from natural gas with an efficiency of 0.58 and emission data based on Uppenberg et al. (2001).

Soil emissions proved to have a large impact on the results. It has been suggested by Crutzen et al. (2007) that the size of nitrous oxides emissions often is underestimated. Therefore, the effect of a double in nitrous oxide emissions was evaluated.

In the future, biomass will most likely become more attractive as fuel for energy, wood and wood products and as raw material for bio-based chemicals and polymers. If only half the biomass produced is available for ammonium nitrate production, the catchment area will have to expand and the average transport distance will increase by about $40 \%$, to $130 \mathrm{~km}$ for straw and $83 \mathrm{~km}$ for Salix. The impact on the results of this increase in transport distance was evaluated in the sensitivity analysis. The effect of a $20 \%$ reduction in yield was also evaluated. 
In this study it was assumed that a part of the produced nitrogen and the gasification ashes were returned to the field where the biomass is grown. If this assumption had not been made, the fertilisers had to be brought in from somewhere else, presumably from fossil fuel based production. This also means that the production of nitrogen from biomass would be higher. A scenario was evaluated where the biomass systems are not self-supporting with fertilisers, but fertilised with conventionally produced fertilisers, using data from Davis and Haglund (1999).

The sensitivity analysis (Table 3 ) showed that assumptions of electricity price, soil emissions and transport distance had little influence on the results. The yield assumptions were important for the eutrophication potential. The results of global warming were sensitive to changes in the system boundaries, although not in the natural gas case since it produced less surplus electricity.

Table 3. Changes (\%) in the impact categories global warming potential (GWP), eutrophication potential (EP) and acidification potential (AP) for the sensitivity analyses

\begin{tabular}{lccc}
\hline & $\begin{array}{c}\text { Natural } \\
\text { gas }\end{array}$ & Salix & Straw \\
\hline Electricity price $+\mathbf{1 0 0 \%}$ & -2 & -4 & -4 \\
GWP & -2 & -4 & -4 \\
EP & -2 & -4 & -4 \\
AP & -3 & -32 & -45 \\
System expansion & -1 & +2 & +0 \\
GWP & -3 & -8 & -8 \\
EP & & & \\
AP & & +30 & +7 \\
N2O emissions +100\% & & & \\
GWP & & +1 & +3 \\
Transport distance $+\mathbf{4 0 \%}$ & & +1 & +2 \\
GWP & & +4 & +5 \\
EP & & & \\
AP & & & \\
Yield -20\% & & +6 \\
GWP & & +18 & +13 \\
EP & & +7 & +10 \\
AP & & \\
Conventional fertilisers & & & \\
GWP & & +15 & +3 \\
EP & & +1 & +2 \\
AP & & +5 & +8 \\
\hline
\end{tabular}

\section{Discussion}

The production of ammonium nitrate fertilisers was here studied. However, most nitrogen fertilisers (such as urea) are produced with ammonia as feedstock, and could therefore also be produced from biomass in a similar way as in this study. A transition to basing production of nitrogen fertilisers on biomass instead of natural gas would have implications for the environment. First of all, this study shows that it would mean a 
clear reduction in greenhouse gas emissions. On an annual basis, approx. 160000 metric ton of nitrogen are sold as fertiliser in Sweden. If all of this nitrogen was to be produced from biomass, a saving of about 380000 ton $\mathrm{CO}_{2}$-equivalents $(0.6 \%$ of Sweden's total emissions of greenhouse gases) would be achieved.

In this study, it was assumed that both ammonium nitrate and electricity was produced. The sensitivity analysis showed that choice of allocation method between these two products had an impact on the results for global warming potential. However, it is possible that ammonium nitrate plants for economical reasons would optimise the production of nitrogen and minimise the energy export, depending on the selling price of the products. This would reduce the need of allocation. The sensitivity analysis also showed that the assumptions regarding yield were important, especially for the eutrophication potential. This is because land use and soil emissions are closely related to eutrophication.

Land is a limited resource, which in the future will have to supply a growing global population with both food and fuel. In the Salix system, land is required for the production of nitrogen fertiliser. From 1 ha of Salix, $3914 \mathrm{~kg}$ of nitrogen can be produced every year. To substitute Sweden's use of nitrogen fertilisers, about 42000 ha of Salix would have to be planted, corresponding to $1.5 \%$ of Swedish cultivated land in 2005 (SJV, 2007). At present, about 15000 ha of Salix are grown, but in a recent Swedish government investigation (SOU, 2007), the target was set to 50000 ha of Salix cultivation by 2013 . The production of nitrogen from Salix would thus require almost a doubling of its area. In short, nitrogen is part of the problem as it would require energy and land inputs, but also part of the solution as it would enable continued high agricultural production, but based on renewable resources.

In the straw system, no land needs to be reserved for the production of nitrogen fertilisers and it thereby does not compete with food production. Being a by-product, straw was only allocated a small share of the wheat production's soil emissions and, as seen in the results, it therefore had less environmental impact than Salix. However there can be drawbacks with using straw, for example an increased risk of soil erosion and a decline in soil organic matter and carbon content. This can have negative effects such as lowered yields, but could also lead to the release of carbon. However, these parameters are very difficult to assess, as they are dependent on many other factors besides crop residue removal, such as soil management and initial carbon stock (Kätterer and Andrén, 1999). We therefore opted not to include soil carbon changes in the calculations.

An important issue when using biomass is the logistics. As seen in the sensitivity analysis, the environmental effects of an increased transport distance are not substantial. However, this is a matter of costs. The production plant has to be large enough to cover the investments required, but not so large that it requires biomass to be transported over too long distances. This is especially important for straw, which is a bulky material. A way to solve the large-scale biomass supply at a reasonable cost could be to use transport means other than trucks, such as train and boat (Forsberg et al., 2007). The storage of biomass can also be problematic. Straw has a low moisture content and can be stored over longer periods of time, while chipped Salix has a high moisture content 
that can lead to microbial activity and hence heat generation (Jirjis, 1995). High dry matter losses, self-ignition and health risks are some of the problems associated with this. The ammonium nitrate plant will have sufficient excess heat for drying the Salix. However, Salix is normally harvested during the winter season, and if it has to be stored at the production facility for the rest of the year, it will require a considerable amount of space. A solution could be to develop a system where Salix is harvested as whole shoots, which can be stored outside for longer periods without the above-mentioned problems (Jirjis, 2005).

The technology of this study is in the future, as biomass gasification is not yet an industrial scale process. Most research and development into gasification technology has focused on wood or wood residues. Gasification of straw is regarded as more complicated due to its high content of potassium and chlorine, components that can give rise to deposits and corrosion. Straw also has a high ash content, which can give rise to problems with sintering and deactivation of the catalyst (Skøtt and Hansen, 2000). The development of efficient gas cleaning technology is also one of the major barriers for commercialisation (Brown et al., 2007). In this study hot gas cleaning was assumed, which is a promising concept as it minimises the problem with tars and particles (Ma et al., 2005). The hydrogen separation can be done with pressure swing adsorption, but was in this study assumed to be carried out with ceramic membranes. The simple design and ability to combine shift and separation in one reactor make ceramic membranes attractive for hydrogen separation (Hamelinck and Faaij, 2002).

As mentioned in the introduction, there are several other possible ways of producing hydrogen from renewable resources. Use of electrolysis might be energy-inefficient, but this is an existing technology that can be used today. The electricity for the electrolysis could be made from renewable sources, for example wind. This would make the production of nitrogen fertilisers very low in greenhouse gas emissions and no land would have to be used for growing biomass. There is, however, a cost issue. According Ni et al. (2006) production of hydrogen from wind would cost about $1.7 € / \mathrm{kg}$, while hydrogen from biomass would cost $0.58-0.88 € / \mathrm{kg}$. As a comparison, hydrogen from natural gas cost about $0.26-0.39 € / \mathrm{kg}$. Further, due to availability and logistic problems connected with biomass, the scale of the biomass based fertiliser production will be smaller compared to natural gas, which could have an impact on the production costs.

Organic farming has many benefits for the environment but suffers from low yields, mainly because mineral fertilisers are not allowed to be used. Instead, many farms use green manuring, i.e. one or two years in the crop rotation are used for growing nitrogenfixing crops such as clover, so the nitrogen can be used by the succeeding crops. This means that the yields per hectare become very low compared with conventional agriculture. If mineral fertilisers based on biomass would be accepted by the organic farming movement this problem would be solved.

\section{Conclusions}

This study demonstrated that producing ammonium nitrate based on biomass feedstock has the potential to reduce the greenhouse gas emissions considerably, compared with using natural gas. When Salix was used, the global warming impact was only $30 \%$ of 
that from natural gas, while the corresponding figure for straw was $22 \%$. The fossil fuel inputs in the biomass systems were very small, but nitrous oxide soil emissions gave a contribution to global warming. The eutrophication potential was higher in the biomass systems due to nutrient leaching from soil, while the acidification was in the same range for both natural gas and biomass. The sensitivity analyses showed that the global warming results were sensitive to choice of allocation method and that yield assumptions had effects on the eutrophication potential.

\section{References}

Ahlgren, S., Baky, A., Bernesson, S., Nordberg, A., Noren, O., Hansson, P.A., 2008. Future fuel supply systems for organic production based on Fischer-Tropsch diesel and dimethyl ether from on-farm-grown biomass. Biosystems Engineering $99,145-155$

Appl, M., 1999. Ammonia: Principles and Industrial Practice. Wiley-Vch, Weinheim, Germany.

Aronsson, P., 2000. Nitrogen Retention in Vegetation Filters of Short-Rotation Willow Coppice. Doctoral thesis. Department of Short Rotation Forestry. Swedish University of Agricultural Sciences, Uppsala, Sweden.

Baumann, H., Tillman, A.-M., 2004. The Hitch Hiker's Guide to LCA. An Orientation in Life Cycle Assessment Methodology and Application. Studentlitteratur, Lund, Sweden.

Berggren, J., 1999. Biobränsletransporter med lastbil och traktor - simulering och analys av bränsleförbrukning och emissioner [Biofuel Transport with Truck and Tractor - Simulation and Analysis of Fuel Consumption and Emissions]. Report 99:07. Swedish University of Agricultural Sciences, Dept of Agricultural Engineering, Uppsala, Sweden.

Bernesson, S., Nilsson, D., Hansson, P.A., 2004. A limited LCA comparing large- and small-scale production of rape methyl ester (RME) under Swedish conditions. Biomass \& Bioenergy 26, 545-559.

Bernesson, S., Nilsson, D., Hansson, P.A., 2006. A limited LCA comparing large- and small-scale production of ethanol for heavy engines under Swedish conditions. Biomass \& Bioenergy 30, 46-57.

Börjesson, P., 2006. Livscykelanalys av Salixproduktion. Lunds tekniska högskola. Institutionen för teknik och samhälle. Avdelningen för miljö- och energisystem. Rapport nr 60, Lund, Sweden.

Börjesson, P.I.I., 1996. Energy analysis of biomass production and transportation. Biomass \& Bioenergy 11, 305-318. 
Brown, D., Gassner, M., Fuchino, T., Marechal, F., 2007. Thermo-economic analysis for the optimal conceptual design of biomass gasification energy conversion systems. Applied Thermal Engineering, In Press, Corrected Proof, doi:10.1016/j.applthermaleng.2007.06.021.

Chum, H.L., Overend, R.P., 2001. Biomass and renewable fuels. Fuel Processing Technology 71, 187-195.

Crutzen, P.J., Mosier, A.R., Smith, K.A., Winiwarter, W., 2007. $\mathrm{N}_{2} \mathrm{O}$ release from agrobiofuel production negates global warming reduction by replacing fossil fuels. Atmos. Chem. Phys. Discuss. 7, 11191-11205.

Davis, J., Haglund, C., 1999. Life Cycle Inventory (LCI) of Fertiliser Production: Fertiliser Products Used in Sweden and Western Europe. SIK-report No 654, Gothenburg, Sweden.

Dimitriou, L., Aronsson, P., 2004. Nitrogen leaching from short-rotation willow coppice after intensive irrigation with wastewater. Biomass \& Bioenergy 26, 433-441.

Dybkjær, I., 2005. New reforming concepts for large scale $\mathrm{NH}_{3}$ plants. $50^{\text {th }}$ Annual Safety in Ammonia Plants and Related Facilities Symposium, September 25-29 2005, Ontario, Canada.

EFMA, 2000a. Best Available Techniques for Pollution Prevention and Control in the European Fertilizer Industry. Production of Ammonia, Booklet No. 1. European Fertilizer Manufacturers Association, Brussels, Belgium.

EFMA, 2000b. Best Available Techniques for Pollution Prevention and Control in the European Fertilizer Industry. Production of Ammonium Nitrate and Calcium Ammonium Nitrate, Booklet No. 6. European Fertilizer Manufacturers Association, Brussels, Belgium.

EFMA, 2008. European Fertilizer Manufacturers Association. http://www.efma.org. Visited 2008-02-01.

Engström, R., Wadeskog, A., Finnveden, G., 2007. Environmental assessment of Swedish agriculture. Ecological Economics 60, 550-563.

Gruvaeus, I., Marmolin, C., 2007. Återföring av aska från bioenergigrödor odlade på åkermark. HS Skaraborg rapport nr 1/07. The Rural Economy and Agricultural Societies, Sweden.

Gustafsson, J., Larsson, S., Nordh, N.-E., 2007. Manual för Salixodlare. Lantmännen Agroenergi. www.agrobransle.se/file?dnl=odlarmanual.pdf. Visited 2008-02-27.

Hamelinck, C., Faaij, A., 2002. Future prospects for production of methanol and hydrogen from biomass. Journal of Power Sources 111, 1-22. 
Hansson, P.A., Baky, A., Ahlgren, S., Bernesson, S., Nordberg, A., Noren, O., Pettersson, O., 2007. Self-sufficiency of motor fuels on organic farms Evaluation of systems based on fuels produced in industrial-scale plants. Agricultural Systems 94, 704 - 714.

Helby, P., Rosenqvist, H., Roos, A., 2006. Retreat from Salix - Swedish experiences with energy crops in the 1990s. Biomass \& Bioenergy 30, $422-427$.

IPCC, 2001. Intergovernmental Panel on Climate Change. Climate Change 2001: The Scientific Basis. Contribution of Working group 1 to the Third Assessment Report of the Intergovernmental Panel on Climate Change. Cambridge University Press, UK. p. 47

IPPC, 2007. Reference Document on Best Available Techniques for the Manufacture of Large Volume Inorganic Chemicals - Ammonia, Acids and Fertilisers. BREF 08.07. Integrated Pollution Prevention and Control, under the European Commission. http://eippcb.jrc.es. Visited 2008-02-24.

ISO, 2006a. Environmental Management - Life Cycle Assessment - Principles and Framework (ISO 14040:2006). European Committee for Standardization, Brussels, Belgium.

ISO, 2006b. Environmental Management - Life Cycle Assessment - Requirements and Guidelines (ISO 14044:2006). European Committee for Standardization, Brussels, Belgium.

Jenssen, T., Kongshaug, G., 2003. Energy consumption and greenhouse gas emissions in fertiliser production. Proceedings No. 509. International Fertiliser Society, York, UK.

Jiménez-González, C., Seungdo, K., Overcash, M., 2000. Methodology for developing gate-to-gate life cycle inventory information. The International Journal of Life Cycle Assessment 5, 153-159.

Jirjis, R., 1995. Storage and drying of wood fuel. Biomass \& Bioenergy 9, 181-190.

Jirjis, R., 2005. Effects of particle size and pile height on storage and fuel quality of comminuted Salix viminalis. Biomass \& Bioenergy 28, 193-201.

Johnsson, H., Mårtensson, K., 2002. Kväveläckage från svensk åkermark - Beräkningar av normalutlakning för 1995 och 1999. Rapport 5248, Swedish Environmental Protection Agency, Stockholm, Sweden.

Kätterer, T., Andrén, O., 1999. Long-term agricultural field experiments in Northern Europe: Analysis of the influence of management on soil carbon stocks using the ICBM model. Agriculture Ecosystems \& Environment 72, 165-179. 
Kyllmar, K., Johnsson, H., 1996. Typområden på jordbruksmark (JRK) - Avrinning och växtnäringsförluster för det agrohydrologiska året 1994/95. Ekohydrologi, vol. 40. Division of Water Quality Management, Swedish University of Agricultural Sciences, Uppsala, Sweden.

Lindfors, L.-G., Christiansen, K., Hoffman, L., Virtanen, Y., Juntilla, V., Hanssen, O.J., Rønning, A., Ekvall, T., Finnveden, G., 1995. Nordic Guidelines on Lifecycle Assessment, vol. 20. Nord. Nordic Council of Ministers, Copenhagen, Denmark.

Lindroth, A., Bath, A., 1999. Assessment of regional willow coppice yield in Sweden on basis of water availability. Forest Ecology and Management 121, 57-65.

Ma, L., Verelst, H., Baron, G.V., 2005. Integrated high temperature gas cleaning: Tar removal in biomass gasification with a catalytic filter. Catalysis Today, 105, 729-734.

Ni, M., Leung, D.Y.C., Leung, M.K.H., Sumathy, K., 2006. An overview of hydrogen production from biomass. Fuel Processing Technology 87, 461-472.

Nilsson, D., 1995. Transportation work and energy requirements for haulage of straw fuels - A comparison between the plants at Såtenäs and Svalöv. Swedish Journal of Agricultural Research 25, 137-141.

Nilsson, D., 1999. SHAM - a simulation model for designing straw fuel delivery systems. Part 2: model applications. Biomass \& Bioenergy 16, 39-50.

Nord Pool, 2007. The Nordic Power Exchange. http://www.nordpool.com. Visited 2007-09-02.

NTMCalc, 2007. Calculation tool from The Network for Transport and Environment (Nätverket för Transporter och Miljön). http://www.ntm.a.se. Visited 2007-0719.

Overend, R.P., 1982. The Average Haul Distance and Transportation Work Factors for Biomass Delivered to a Central Plant. Short Communication, Biomass. vol. 2, no. 1, Applied Science Publishers Ltd, England.

Saigne, M., 1993. Energy Balance in an Ammonium Nitrate-Nitric Acid Plant. Proceedings No. 338. International Fertiliser Society, York, UK.

SCB, 2007a. Inflation Calculator. Statistics Sweden. http://www.scb.se. Visited 2007$10-01$.

SCB, 2007b. Price Indices and Prices in the Food Sector - Annual and Monthly Statistics - 2006:11. Statistics Sweden. 
SJV, 2007. Jordbruksstatistisk årsbok 2007 (Yearbook of agricultural statistics 2007). Swedish Board of Agriculture and Statistics Sweden.

Skøtt, T., Hansen, M.T., 2000. Danish Biomass Solutions - reliable and efficient. Center for Biomass Technology. The Danish Energy Authority. http://www.videncenter.dk/exportcat/policy_and_market.pdf. Visited 2008-0305 .

Smeets, E., Faaij, A., 2005. Future Demand For Fertilizer From Bioenergy Crop Production 73rd IFA Annual conference. Kuala Lumpur, Malaysia, 6-8 June 2005.

Smil, V., 2001. Enriching the Earth: Fritz Haber, Carl Bosch, and the Transformation of World Food Production. MIT Press, Cambridge.

SOU, 2007. Bioenergi från jordbruket - en växande resurs. Statens offentliga utredningar. Swedish Government Official Reports. Report SOU 2007:36. Stockholm, Sweden.

Swedish Environmental Protection Agency, 2005. Sweden's National Inventory Report 2005 - Submitted under the United Nations Framework Convention on Climate Change. Report 5451, Swedish Environmental Protection Agency. Stockholm, Sweden.

Tidåker, P., 2003. Life Cycle Assessment of Grain Production Using Source-Separated Human Urine and Mineral Fertiliser. Report 251. Department of Agricultural Engineering, Swedish University of Agricultural Sciences, Uppsala, Sweden.

Uppenberg, S., Alemark, M., Lindfors, L.-G., Marcus, H.-O., Stripple, H., Wachtmeister, A., Zetterberg, L., 2001. Miljöfaktabok för bränslen. Del 2. Bakgrundsinformation och Teknisk bilaga IVL Rapport B1334B-2, Stockholm, Sweden.

Välimaa, C., Stadig, M., 1998. Växtnäring i livscykelanalys - mineralgödselanvändning i spannmålsodling [Nutrients in Life Cycle Assessment]. SIK-report No. 637, The Swedish Institute for Food and Biotechnology, Gothenburg, Sweden. 